Journal

of Geography

Politics and Society

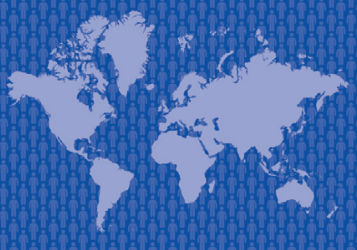

$7(2) / 2017$

\section{Journal of Geography, Politics and Society}

$2017,7(2), 32-42$

DOI 10.4467/24512249JG.17.013.6629

\title{
LVIV OBLAST: URGENT SOCIO-ECONOMIC PROBLEMS IN THE CONTEXT OF EUROPEAN INTEGRATION
}

\author{
Myroslav Biletskyi (1), Yaroslav Ivakh (2), Liubov Kotyk (3) \\ (1) Faculty of Geography, Ivan Franko National University of Lviv, Doroshenka 41, 79000 Lviv, Ukraine, \\ e-mail: biletskiymyroslav@gmail.com (corresponding author) \\ (2) Faculty of Geography, Ivan Franko National University of Lviv, Doroshenka 41, 79000 Lviv, Ukraine, \\ e-mail: ivakh.yaroslav@gmail.com \\ (3) Faculty of Geography, Ivan Franko National University of Lviv, Doroshenka 41, 79000 Lviv, Ukraine, \\ e-mail: kotykluba@gmail.com
}

\section{Citation}

Biletskyi M., Ivakh Ya., Kotyk L., 2017, Lviv oblast: urgent socio-economic problems in the context of European integration, Journal of Geography, Politics and Society, 7(2), 32-42.

\begin{abstract}
The paper summarizes the contribution of the Ukrainian and Polish scholars into the study of challenges of European integration in Ukraine. It proves the importance of researching socio-economic problems of Lviv region in the context of European integration. We have described the general characteristics of Lviv region and revealed the advantages of economic and geographical position of the region. It has been analyzed the problems of structural changes in the region's economy, the challenges of reindustrialization, the investment and foreign economic activity of Lviv region. The special emphasis has been put on the need to transform the region's economy in order to overcome the long-lasting socio-economic crisis.
\end{abstract}

\section{Key words}

Lviv oblast, European integration, socio-economic problems, economy transformation, reindustrialization, investment activity, foreign economic activity.

\section{Introduction}

Under the circumstances of a long-lasting socioeconomic crisis in Ukraine, which has been caused by the transition from the planned economy to the market economy model, the introduction of democratic norms across many life spheres, the development of civil society, the intensified aggression on the part of Russia, and military action in the east of the country (2014-2017), the study of the European integration challenges is more relevant than ever. The European integration as a civilizational choice of Ukraine is a means to overcome the technological obsolescence of the economy and the creation of new working places by attracting investments and introducing innovational technologies, the possibility of Ukrainian goods and services to enter the global market, the prospect of increasing the quality and the standard of living of the population, the elimination of corruption, reducing the crime rate by introducing European legal norms and standards of living.

The challenges of European integration have been thoroughly studied by social geographers both 
in Ukraine and in the countries that have successfully resolved them and got integrated into the European space (Poland, Estonia, Czech Republic etc.). Specifically, the challenges of transforming the economic complex of the state have been researched by O. Shabliy (Шаблій, 2001), L. Nemets, Y. Oliynyk, K. Nemets (Hємець et al., 2003), H. Balabanov, V. Nahirna, O. Nyzhnyk, (Балабанов et al. (eds.), 2003), V. Smal (Смаль, 2011), H. Pidhrushnyi (Підгрушний, 2009), K. Mezentsev, H. Pidhrushnyi, N. Mezentseva (Мезенцев et al., 2014), I. Pylypenko (ПилипенKo, 2015); the development of modern forms of the combination of enterprises on the territory of Ukraine has been studied by D. Stechenko (СтеченKo, 2002); the problems of trans-border cooperation have been investigated by N. Mikula (Мікула, 2004); the problems of investment and innovational development have been studied by Y. Kachaiev (КачаєB, 2007), V. Kravtciv, M. Melnyk, V. Anonov (Кравців et al., 2011); the problems of the standard and quality of living of the population have been researched by I. Hukalova (Гукалова, 2009). In Poland, the socioeconomic challenges of Ukraine in the context of the European integration have been studied by $\mathrm{P}$. Bajda (2011); the structural improvements in the Ukrainian economy and the development of the investment activity have been investigated by J. Fiszer (2015); the effect of the integrational processes on the development of Ukrainian-Polish relationship has been researched by R. Świtala (2014); the challenges of Polish-Ukrainian trans-border relationship have been studied by B. Kawalko (2011).

The scholars have pointed out that in the context of the European integration of Ukraine, the most urgent socio-economic problems are connected with the structural changes of the economy (Шаблій, 2001; Мезенцев et al., 2014; Fiszer, 2015), the development of the investment activity (Смаль, 2011; Fiszer, 2015) and small business (Балабанов et al. (eds.), 2003), the transformation of the foreign economic activity (Мікула, 2004; Bajda, 2011; Kawalko, 2011), the polarization of the territorial development (Пилипенко, 2015) and an increase in the population's standard and quality of living (ГукалоBa, 2009; Fiszer, 2015). Since the studies covered the whole territory of Ukraine, the scholars left out the distinctive features of the socio-economic development of specific regions of Ukraine in the context of European integration, one of which is Lviv oblast.

\section{An overview of Lviv oblast}

Lviv oblast is situated in the west of Ukraine, borders Poland (the length of the border is $258 \mathrm{~km}$ ), is included in the Carpathian European region and "Bug" European region, and is a leader in the socioeconomic development of the Western socio-geographical region of Ukraine. In the greater context of Ukraine the region is characterized by (Tab. 1):

- the high number of the industrial plants that market innovative products;

- above average indicator of the number of the population, the natural decrease of the population, the average age of the population, the level of unemployment, the gross regional product;

- below average indicator of the territory, the potential of integral natural resources; the gross regional product per person; the amount the subjects of economic activity with 1,000 people, the volume of exported and imported services, direct investments into the oblast and from the oblast into the global countries' economies.

The oblast stands out by its favorable economic and geographic location due to the immediate neighborhood with the EU state - Poland, the proximity to most EU states (Fig. 1), the developed transport system (international highways E-5 (KyivLviv-Lisbon), E-17 (Lviv-Lublin-Warsaw), E-40 (LvivKrakow-Frankfurt), E-471 (Lviv-Stryi-Chop), Danylo Halytskyi International Airport Lviv), and customs infrastructure (customs checkpoints: Rava-Ruska Hrebenne (Hrebenne), Krakivets - Korchova (Korczowa), Smilnytsia-Krostsenko (Kroscienko); automobile and pedestrian checkpoints: Shehyni - Medica (Medyka), Uhryniv - Dolhobychuv (Dolhobyczow); the checkpoint: Hrushiv - Budomezh (Budomierz)).

\section{The problems of structural changes in the economy}

The economic complex of Lviv oblast is formed by 120.4 thousand economic entities, $15.5 \%$ of which are comprised by enterprises and $84.5 \%$ are individual entrepreneurs (Діяльність суб'єктів ..., 2016). With a stable upward dynamics of growth in the number of business entities (16.3\% growth compared to 2010), the major problem is their low economic activity (only 65\% of businesses are economically active (Державна служба статистики України)), as well as the growing "shadow" economic activity, which is caused both by the growth of the tax burden created by the state and local governments (especially the payroll tax) and by the low culture of social responsibility of businesses, corruption, the lack of trust in the state, legal nihilism, the lack of active fiscal policy. This results in the downward dynamics in the number of employed workers (Tab. 2) and an increase in unemployment, 
Tab. 1. The position of Lviv oblast in Ukraine according to main macroeconomic indicators, 2015

\begin{tabular}{|c|c|c|c|c|}
\hline \multirow[b]{2}{*}{ Indicators } & \multirow{2}{*}{$\begin{array}{l}\text { Lviv oblast, } \\
\text { the number } \\
\text { (position) }\end{array}$} & \multicolumn{3}{|c|}{ Ukraine } \\
\hline & & Average & Maximum (oblast) & $\begin{array}{l}\text { Minimal } \\
\text { (oblast) }\end{array}$ \\
\hline The total area, $\mathrm{km}^{2}$ & $21833(17)$ & 24080 & $\begin{array}{c}33310 \\
\text { (Odeska obl.) }\end{array}$ & $\begin{array}{c}839 \text { (c. Kyiv) } \\
8097 \text { (Chernivetska obl.) }\end{array}$ \\
\hline $\begin{array}{l}\text { Integral potential of natural resources, } \\
\% \text { o }\end{array}$ & $37.653(8)$ & 40.000 & 122.462 (Donetska obl.) & $\begin{array}{c}12.703 \\
\text { (Chernivetska obl.) }\end{array}$ \\
\hline $\begin{array}{l}\text { The current number of population, } \\
\text { thousands of people. }\end{array}$ & $2534.2(5)$ & 1660.6 & 4265.1 (Donetska obl.) & 909.9 (Chernivetska obl.) \\
\hline Natural population growth/decrease, \%o & $-2.0(7)$ & -4.2 & $\begin{array}{c}1.8 \text { (c. Kyiv) } \\
1.2 \text { (Rivnenska obl.) }\end{array}$ & -10.3 (Chernihivska obl.) \\
\hline The average age of the population, years. & $39.6(6)$ & 40,9 & 43.7 (Luhanska obl.) & 36.8 (Zakarpatska obl.) \\
\hline The level of unemployment, $\%$ & $1.5(6)$ & 1.9 & $\begin{array}{c}3.7 \\
\text { (Kirovohradska obl.) }\end{array}$ & $\begin{array}{c}0.9 \text { (c. Kyiv), } \\
1.1 \text { (Odeska obl., } \\
\text { Zakarpatska obl.) }\end{array}$ \\
\hline Gross regional product, millions of UAH & $72923(7)$ & 63476 & $\begin{array}{c}357377 \text { (c. Kyiv), } \\
176540 \\
\text { (Dnipropetrovska obl.) }\end{array}$ & $\begin{array}{l}21676 \\
\text { (Ternopilska obl.) }\end{array}$ \\
\hline Gross regional product per person, UAH & $28731(11)$ & 36904 & $\begin{array}{c}124163 \text { (c. Kyiv) } \\
46058 \text { (Kyivska obl.) }\end{array}$ & $\begin{array}{c}14079 \text { (Luhanska obl.), } \\
16552 \text { (Kyivska obl.) }\end{array}$ \\
\hline $\begin{array}{l}\text { The number of economic entities per } \\
1,000 \text { people }\end{array}$ & $24(9)$ & 27 & $\begin{array}{c}83 \text { (c. Kyiv), } \\
36 \text { (Mykolaivska obl.) }\end{array}$ & 17 (Zakarpatska obl.) \\
\hline $\begin{array}{l}\text { The number of industrial plants that } \\
\text { market innovative products }\end{array}$ & $44(3)$ & 22.8 & 66 (Kharkivska obl.) & $\begin{array}{l}5 \text { (Luhanska obl.), } \\
7 \text { (Volynska obl.) }\end{array}$ \\
\hline $\begin{array}{l}\text { The number of exported goods, millions } \\
\text { USD }\end{array}$ & $1206,3(10)$ & 1525.1 & $\begin{array}{c}8742.9 \text { (c. Kyiv), } \\
6399.0 \\
\text { (Dnipropetrovska obl.) }\end{array}$ & 108.3 (Chernivetska obl.) \\
\hline $\begin{array}{l}\text { The number of imported goods, millions } \\
\text { USD }\end{array}$ & $1447.9(5)$ & 1500.7 & $\begin{array}{c}14495.4 \text { (c. Kyiv), } \\
3225.3 \\
\text { (Dnipropetrovska obl.) }\end{array}$ & 78.4 (Chernivetska obl.) \\
\hline $\begin{array}{l}\text { The amount of exported services, mil- } \\
\text { lions USD }\end{array}$ & $369.7(4)$ & 389.5 & $\begin{array}{c}2803.0 \text { (c. Kyiv), } \\
896.9 \text { (Odeska obl.) }\end{array}$ & $\begin{array}{c}14.0 \text { (Luhanska obl.) } \\
17.3 \text { (Chernihivska obl.) }\end{array}$ \\
\hline $\begin{array}{l}\text { The amount of imported services, mil- } \\
\text { lions USD }\end{array}$ & $50.2(12)$ & 220.9 & $\begin{array}{c}2273.2 \text { (c. Kyiv), } \\
402.1 \\
\text { (Dnipropetrovska obl.) }\end{array}$ & 1.8 (Chernivetska obl.) \\
\hline $\begin{array}{l}\text { Direct foreign investments in the region, } \\
\text { mln USD }\end{array}$ & $1248.1(7)$ & 1734.9 & $\begin{array}{c}22600.4 \text { (c. Kyiv), } \\
7182.9 \\
\text { (Dnipropetrovska obl.) }\end{array}$ & 50.1 (Ternopilska obl.) \\
\hline $\begin{array}{l}\text { Direct investments from the region into } \\
\text { the world's economies, mIn USD }\end{array}$ & $34.5(4)$ & 248.4 & $\begin{array}{c}5391.2 \text { (Donetska obl.) } \\
633.5 \text { (c. Kyiv) }\end{array}$ & 0.1 (Khersonska obl.) \\
\hline
\end{tabular}

Source: made by authors on the based Державна служба...; Україна у цифрах ..., 2016.

economic migration and social tension in the oblast. The latter is aggravated by the problem of salary payments and setting the minimum wage: since 2017 3200 UAH (110 EUR), in comparison, the minimum wage in neighboring Poland constitutes 1460 PLN (335 EUR).

The positive side of the structural improvements in the economic sector of Lviv oblast is an increase in the size of the medium and small business entities (51\% and $30 \%$ of employed workers accordingly; $34 \%$ and $37 \%$ by the number of marketed products), as well as the fact that this indicator is reaching the European norms (small and medium businesses in Poland account for over $90 \%$ of employed workers and $50 \%$ of gross regional product). This allows the oblast to resist the monopolization of the regional market by big enterprises, improves the standard and the quality of produced goods and delivered services through the competition between medium and small manufacturers, stimulates innovative activity in small and medium business segment. 


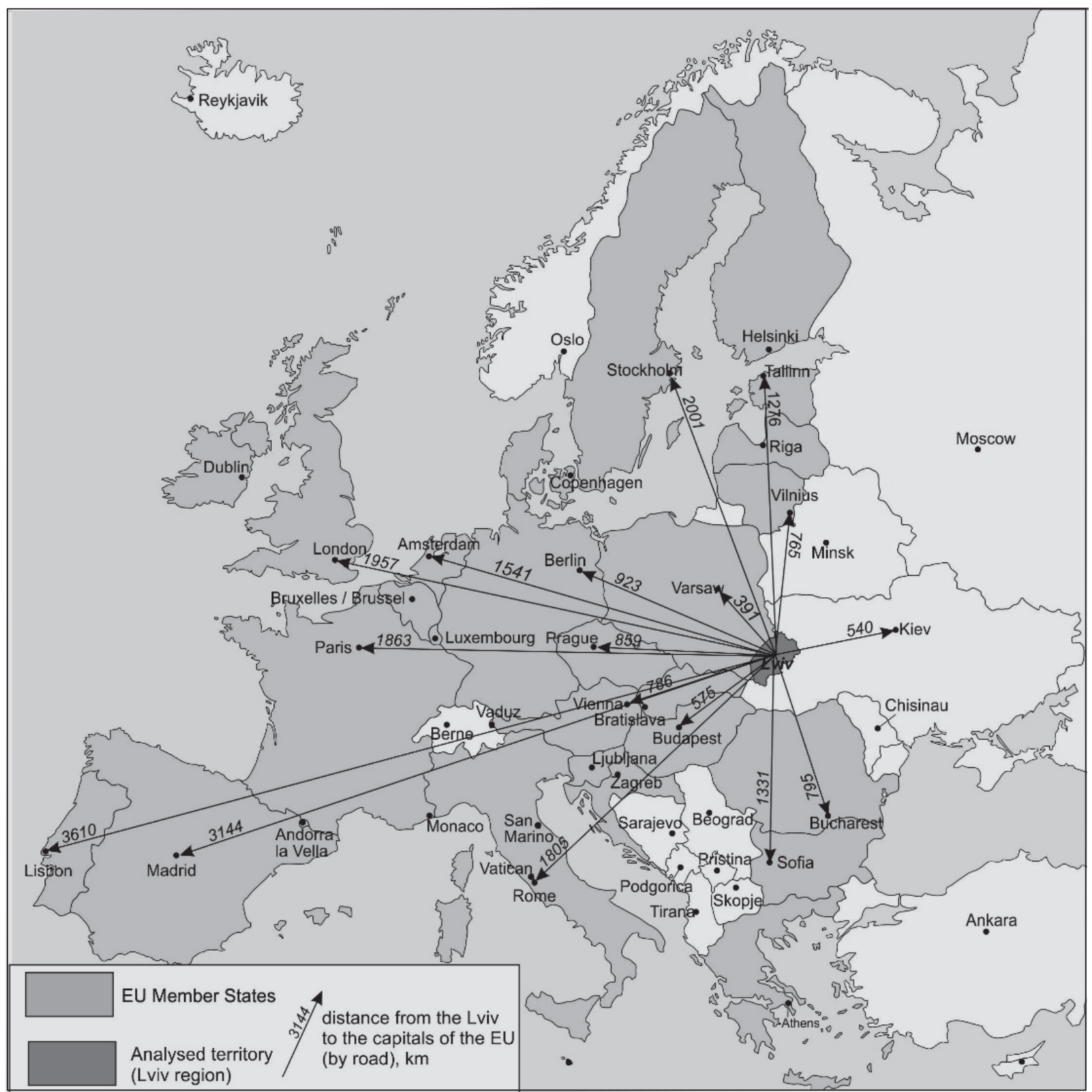

Fig. 1. The distance from Lviv to European capital cities

Source: made by authors on the based www.della.com.ua/distance; www.d-maps.com.

One of the problems is that the state owns a lot of bankrupt, not competitive, huge enterprises mostly in the mining (SE "Sirka", Novyi Rozdil; SE "Mezhyrichanska Mine", Chervonograd, SE "Stepova Mine", Hluhiv) and engineering (SE "Lviv Radio Engineering Plant", Lviv, SE "Lviv State Aircraft Repair Plant", Lviv; PJSC "Drogobych machinebuilding plant", Drohobych) industries that require the search for an effective investor. Given that these businesses played the city development role in the Soviet period, they are now the centers of depressed areas with low investment attractiveness.

There have been changes in the sector structure of the region's economy (2002-2005): the share of the sold products by business entities in manufacturing, transport and storage sector has increased (Fig. 2, 3), and these sectors actively take advantage of the economic and geographical location of the region in their development, and, first of all, the proximity to the EU countries. Another benefit is the development of the dynamic information and communications sector ( $2 \%$ of the sold products in the region, 2015) and the high competitiveness of these businesses both on Ukrainian and the global services markets ("SoftServe", "GlobalLogic", "Eleks", "N-iX", “EPAM", etc.).

In terms of the territory, the biggest number of businesses are registered and working in the centers of active transformation of Lviv oblast's economy: the oblast center - the city of Lviv $(45.6 \%$ of businesses 
Tab. 2. The main indicators of the activity of economic entities in Lviv oblast, 2010-2015

\begin{tabular}{|l|c|c|c|c|c|}
\hline \multicolumn{1}{|c|}{ Indicators } & 2010 & 2012 & 2013 & 2014 & 2015 \\
\hline $\begin{array}{l}\text { The number of economic entities } \\
\text { including: }\end{array}$ & 103517 & 74454 & 82757 & 117732 & 120447 \\
\hline enterprises & 20343 & 17325 & 18762 & 18582 & 18633 \\
\hline individual entrepreneurs & 83174 & 57122 & 63995 & 99150 & 101814 \\
\hline $\begin{array}{l}\text { The number of employed workers, thousands of people } \\
\text { including }\end{array}$ & 544.6 & 490.4 & 478.4 & 499.9 & 478.9 \\
\hline enterprises & 403.8 & 377.0 & 356.3 & 345.5 & 331.6 \\
\hline individual entrepreneurs & 140.8 & 113.4 & 122.1 & 154.4 & 147.3 \\
\hline The average salary, UAH & 1941 & 2578 & 2789 & 2961 & 3405 \\
\hline $\begin{array}{l}\text { The number of marketed products, mln UAH } \\
\text { including: }\end{array}$ & 109323.6 & 143510.9 & 144168.0 & 166394.0 & 207671.8 \\
\hline enterprises & 98047.1 & 131984.6 & 131081.6 & 149707.9 & 183102.3 \\
\hline individual entrepreneurs & 11276.5 & 11526.3 & 13086.4 & 16686.1 & 24569.5 \\
\hline
\end{tabular}

Source: made by authors on the based Діяльність суб'єктів...., 2016; Головне управління... .

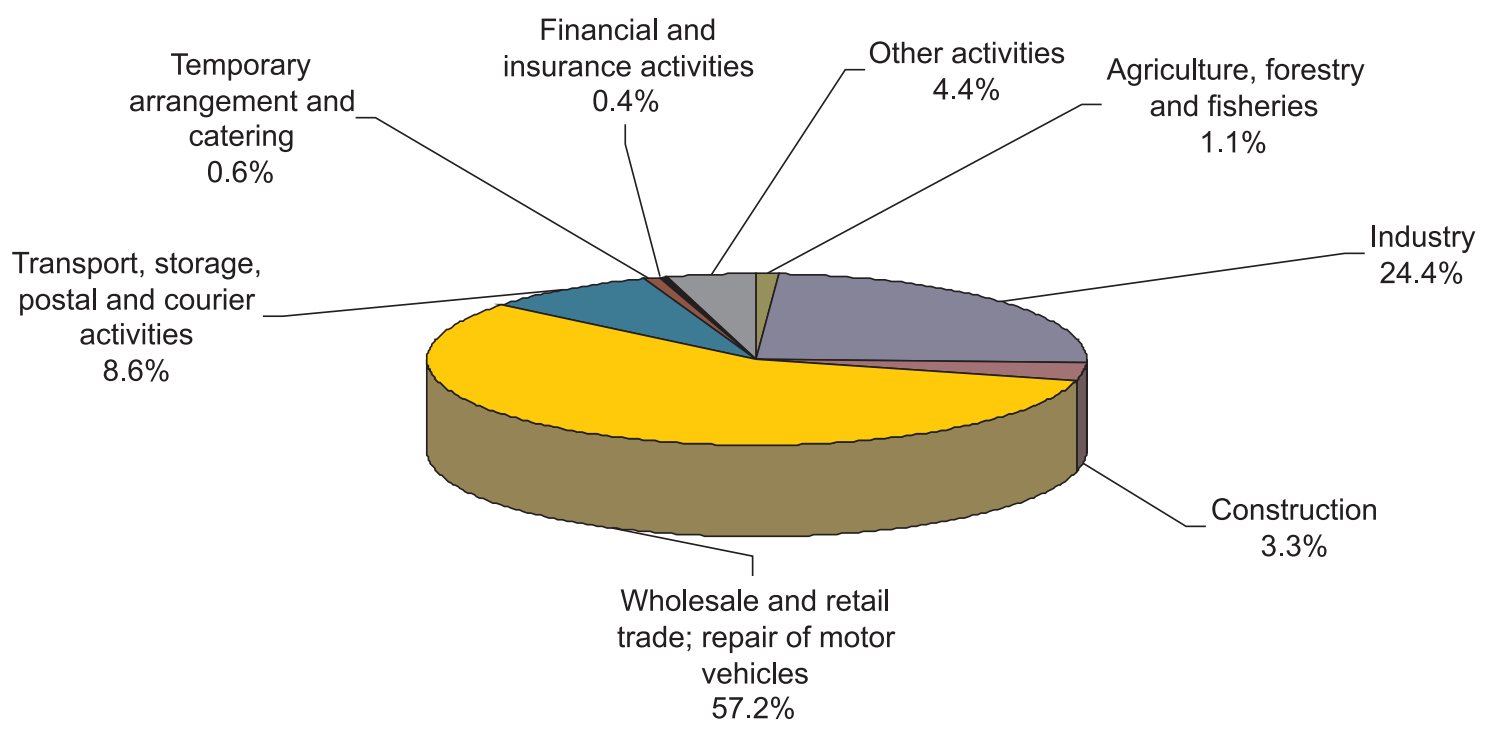

Fig. 2. The volume of marketed products by the type of economic activity, 2002

Source: Головне управління...

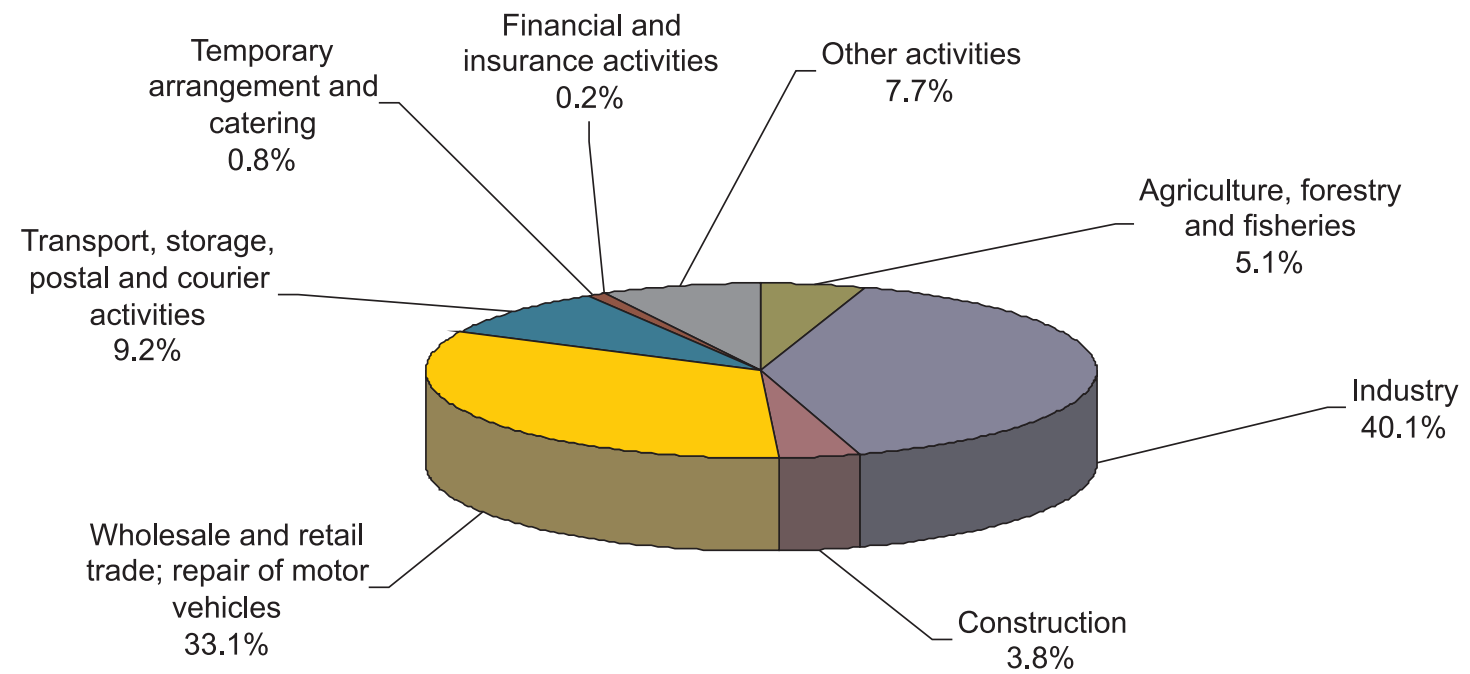

Fig. 3. The volume of marketed products by the type of economic activity, 2015

Source: Головне управління... 


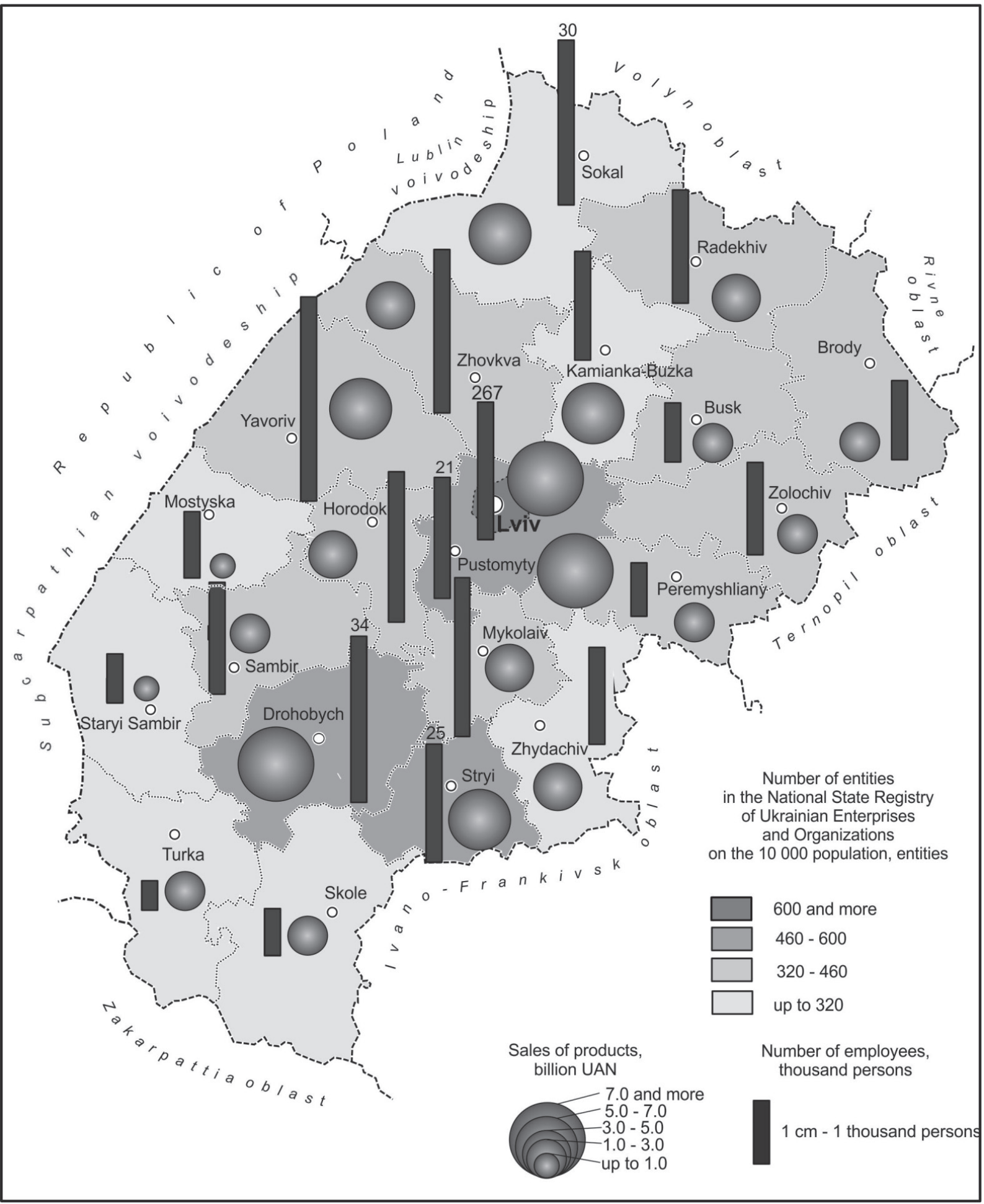

Fig. 4. The functioning of business entities in Lviv oblast, 2015

Source: made by authors on the based Діяльність суб'єктів...., 2016.

of the region; $62.7 \%$ of the sold products); the economically attractive Pustomuty district $(4.8 \%$ and $6.4 \%)$, Stryi district $(3.3 \%$ and $1.2 \%)$, the center of tourism and recreation development in Truskavets city $(1.6 \%$ and $0.8 \%)$; the area of oil and gas mining in Drohobych district (4.7\% and 2.6\%).

One of the relevant problems is the polarization in the development of Lviv oblast, namely the contrast between the center in Lviv and the depressed (Sokal and Zhydachiv) and outdated (Skole, Turka, Staryi Sambir, Mostyska, Kamianka Buzka) districts (Fig. 4). An example of overcoming the depression and stagnation in the economic development could be Yavorivskyi district, which took advantage of the neighborhood with Poland, created "Yavoriv" free economic zone (1999), and 
ensured the development of new competitive companies in this district, namely in the chemical ("ProPet" LLC, "Sniezka-Ukraine" LLC), woodwork ("Euroshpon" LLC), and light ("Joha Ukraine" LLC) industries. The creation of SEZ "Resort Polis Tuskavets" has attracted investments to the spa facilities in Truskavets (117,1 million USD in 2001-2011). The withdrawal of benefits negatively affected the development of economic zones so now is the time for their reestablishment.

In order to promote economic activity and coordinate the operation of existing business entities, three clusters have been created: (an IT cluster (Lviv, 2010, based on the resources of "SoftServe Inc.", "ELEKS Software", "N-iX", and "Symphony Solutions" companies; a cluster of wood work and furniture production (Lviv, 2010, the resources of "Svitanok", "Buk-Holding", "Uniplyt", "Lviv furniture factory"), a tourism cluster (Lviv, travel agencies, hotels, businesses in restaurant and hospitality industries). The industrial park "Riasne-2" started its operation in 2016 ("Fujikura" (the production of electronic wires and connectors for automobiles) with the investments of 75 million USD).

\section{Reindustrialization challenges}

For centuries Lviv oblast has fallen behind eastern regions of Ukraine and industrial Polish regions in the level of industrial development because it was either on the periphery of the empires or was included in the newly-formed states as their periphery. The industrialization during the Soviet time was at first aimed at receiving the necessary for the empire resources quickly, and later at active exploitation of the cheap and skilled labor resources. This triggered the development of mining, energy, forestry, light industries in Lviv oblast in 1940-1950s; and the development of engineering and chemical industries in 1960-1970s (Шимонович, 2001; Назарук, 2008). However, there were no finished technological chains in these industries. Engineering, especially in the military-industrial complex, was targeted at assembly manufacturing or the production of individual units and components ("Lviv Armored Factory", "Lviv Radio Electronics Plant"); while chemical industry mainly produced raw materials and semi-finished goods with low added value.

In the 1990s, during the first years of the Ukrainian independence, there was a sharp decline in production in many fields, especially in the industries that were deeply integrated into the imperial structures (engineering, chemical industry). The recession of the production deepened because of Russia's direct discriminatory economic policies (for example, "Lviv Bus Plant" (2001) was acquired by the Russian capital (70.4\% of shares of "Seal Auto" LLC) to eliminate a competitor). Wood work and light industry declined (1991-2001) due to the low purchasing power of the population. Also, the enterprises were technologically outdated, their products were not competitive, and their energy and material consumption was high compared with the international counterparts thus these factors contributed to the recession. This led to the reduction of the share of the industry in the total gross regional product of Lviv oblast: 2000 - 23\%, $2015-17 \%$, indicating a catastrophic deindustrialization of the region (Fig. 5). This gives rise to the social problem, since unemployed workers with higher technical education had to either seek work place abroad, or retrain for other industries such as construction and trade.

The leading fields of the oblast's industry in 2015 were food (32.8\% of the industry production) and energy (17.7\%) sectors; the share of engineering dropped to $7.2 \%$, which was the oblast's specialization industry until 1990s. The presented facts indicate that Lviv oblast requires an effective policy of reindustrialization, which will enable the balanced use of the natural and labor resources and will help to increase the gross regional product.

While developing the policy of reindustrialization, it is important to take into account the factors which had been formed because of the difficult political and socio-economic situation in Ukraine after the Russian military aggression (2014). The military action in the east of Ukraine did not affect the industrial infrastructure of the western region but decreased its investment attractiveness and aggravated the innovative and investment climate (military mobilization of the population, additional military tax, the activity of volunteer movements supporting the army etc.). Foreign investors are reluctant to invest money and start big projects in the country at war, and the military expenses limit internal investments. The political instability and frequent changes in the economic legislation, the corrupted judicial system that covers the raiders, keeps Ukrainian and foreign entrepreneurs from modernization and expanding their industrial production. The economic crisis and the lack of attractive loans for local businesses make the production more expensive due to the pay of inflationary rent.

The advantage is that the low cost of labor attracts the investors of small, low-capital manufacturing projects that require a lot of labor force (the light industry - "Vesna" LLC, "Svitanok" LLC): the establishment of the European standards makes these products competitive on the global market. 


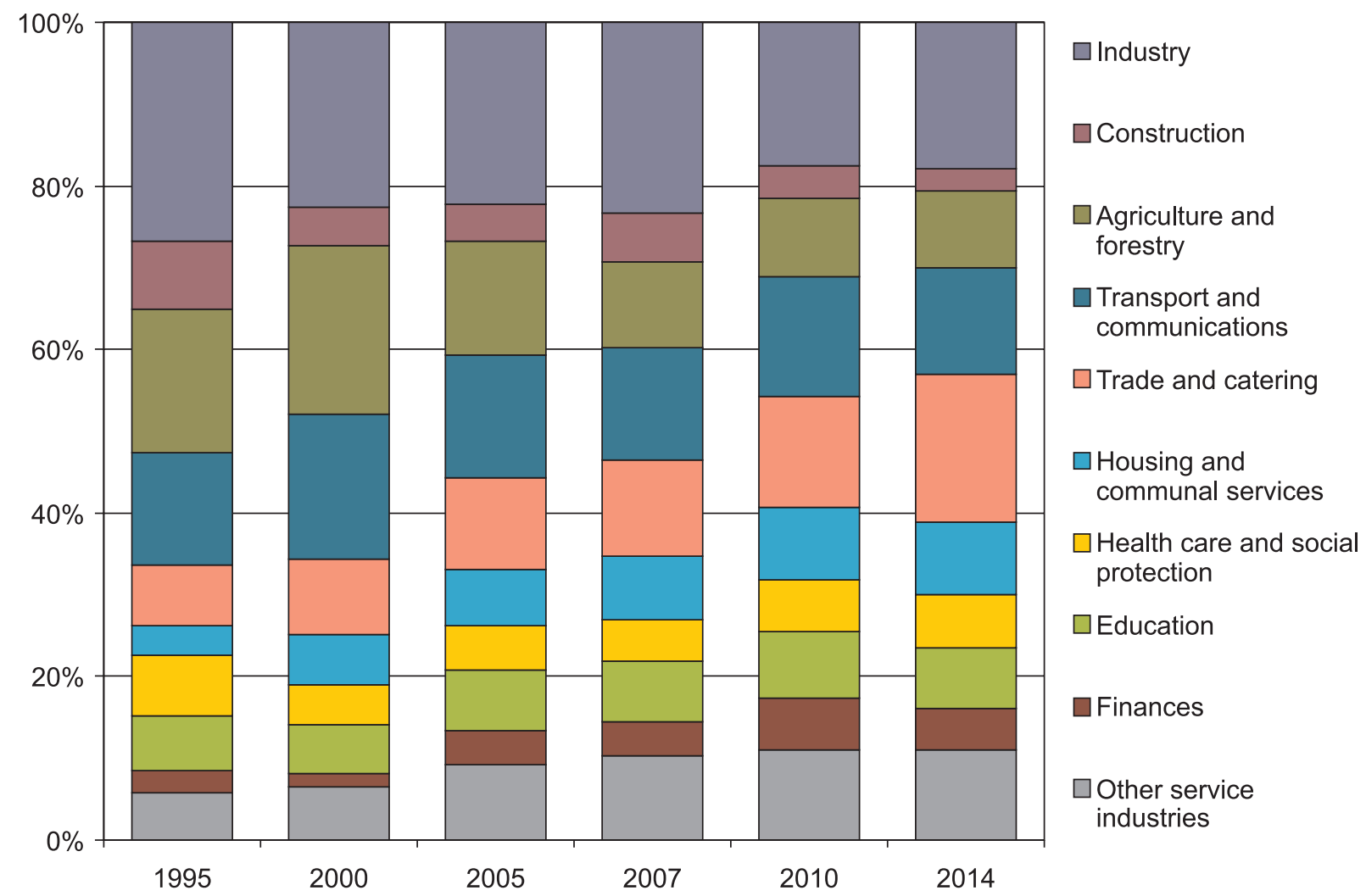

Fig. 5. The structure of gross regional product of Lviv oblast, 1995-2014

Source: made by authors on based Львівська область у цифрах ..., 2016.

Another benefit is that Lviv oblast has the densest network of settlements of different size in Ukraine, which have enough industrial sites with the engineering infrastructure and a dense network of routes. Also, the oblast has a variety of resources for industrial processing, which are created in agriculture and forestry industries. The oblast has a high level of water supply, many deposits of mineral resources, including the recently discovered deposits of shale gas. Therefore, the ways of reindustrialization of Lviv oblast should both take into account the opportunities of the existing enterprises and attract foreign investment and technologies. In our opinion, the oblast's reindustrialization should be implemented in the following directions:

- partial modernization of the existing industrial enterprises with the radical decrease in their energy and material consumption (this especially concerns food industry enterprises where the Soviet era technologies are still in use). Thus there are grounds for the rapid renovation of the alcohol, sugar, dairy, and tin enterprises. Such modernization may partly cover more modern companies in the wood and construction industries;

- the development of the alternative energy sector (wind, solar), shale gas mining, biofuels production, waste recycling, which will require wide attraction of foreign investment and technologies.
Over time, this will enable production of technological equipment for the alternative energy and waste management in the oblast. This will allow to use the scientific and technical potential of the oblast;

- creation of small enterprises of light industry, mechanical engineering, woodworking, focused on cheap labor force potential, local raw materials, international cooperation. In the long term, the transition to production of technologically more complex products may be expected;

- re-establishment of big engineering enterprises, which can already be seen by the example of "Electron" group. First of all, rebuilding of strategic enterprises, of the military-industrial complex, and the agricultural engineering enterprises, which are in high demand, is required;

- creation of industrial clusters that could comprehensively use available local resources based on the principle of sustainable development. Special emphasis should be put on establishing the enterprises of deep processing of raw materials (organic synthesis chemistry, wood chemistry, recycling of plastic and glass containers, bioenergy, and the production of high-tech building materials). 


\section{The challenges of foreign investments and foreign economic activity}

During 2005-2015, Lviv oblast economy received direct foreign investments (equity) in the amount of 1248.1 million USD. The most attractive sectors for investors are manufacturing (36.7\% of invested equity), finance and insurance (35.2\%), transportation and warehousing $(8.6 \%)$, real estate $(6.9 \%)$. Investors were reluctant to invest in the most dynamic sectors of the oblast such as temporary accommodation and catering $(0.7 \%$ of invested equity), wholesale and retail trade, repair of motor vehicles $(3,2 \%)$, construction $(1,4 \%)$. A significant problem is the decline in the oblast's investment attractiveness because of the socio-economic crisis in Ukraine, the growing corruption and military action in the east of the country, which led to an outflow of foreign investments from Lviv oblast (foreign investment fell by $26.6 \%$ by the end of 2015 compared to the beginning of 2014). The largest outflow of investments (2015) took place in such sector as art, sports, entertainment $(-34.5 \%)$, temporary accommodation and catering $(-33.1 \%)$, construction $(-15.2 \%)$, real estate $(-13.7 \%)$ (Статистичний щорічник ..., 2016).

The positive aspect is that the EU member states prevail among the countries investing in the Lviv oblast (2015) such as Poland (30.7\% of foreign equity), Cyprus (17.1\%), Austria (14.3\%), Germany (6.5\%), Switzerland (5.6\%), and Denmark (4.9\%). The oblast's most attractive sectors for the investors from Poland are finance and insurance $(81.6 \%$ of foreign equity); for Cyprus investors these are manufacturing (44.9\%), transportation and warehousing (37.6\%); German investors are interested in manufacturing $(92.2 \%)$, wholesale and retail trade, repair of motor vehicles (4.4\%); Austria - finance and insurance (69.9\%), manufacturing (18.5\%) (Інвестиції ...., 2015).

One of Lviv oblast's challenges is the territorial disparities in attracting direct foreign investments, the lowest investment per 1,000 entities has been the in peripheral districs of the region (Turka, Skole, Zolochiv, Brody) and border regions (Staryi Sambir, Mostyska, Zhovkva) (Статистичний щорічник ...., 2016). This may be explained by the inactivity of the local communities in the cooperation with potential investors, the lack of modern investment projects in the oblast, inconsistency and frequent changes in the legislation in the field of foreign investment, corruption of the local authorities, non-compliance with the requirements of the initiated investment projects by the regional and local authorities, the lack of effective state guarantees of investment protection under unexpected circumstances, the low level of cross-border economic cooperation.

One of the problems is the "shadow" activity, the usage of offshore countries (Cyprus) to make direct investments from Lviv oblast into the world's countries. At the beginning of 2016 there were direct investments (34.5 million USD) into three countries from the region, namely Cyprus (58.3\%), Poland (13.4\%) and Russia (28.3\%). As for the positive aspects, the investments in Russia have dropped (36.7\% in 2014), yet there has been a negative trend, namely the growth of offshore Cyprus investment (by $12.3 \%$ compared to 2014), which illustrates the export of capital from the oblast and non-residents' evasion from paying taxes. Another problem is the lack of direct investment from the oblast to the economies of highly developed countries, where we could adopt new production technologies, new methods of business management, a new range of products and services for their further usage in the oblast's economy.

Due to the European integration, there have been changes in the foreign economic activity. The total export of goods in the oblast amounts (2015) 1.2 billion USD, the total of imported goods comprises 14.5 billion USD, the export of services is 0.4 billion USD, the import of services equals 0.05 billion USD (Статистичний щорічник ...., 2016). Concerning the benefits, there was an increase in the number of the EU states in the foreign economic activity of Lviv oblast (Tab. 3).

One of the challenges of the oblast's economy is a negative balance of foreign trade in goods and services, which leads to the dependency of the region's economic development on the fluctuations of the national currency and economic policies of the partner states, and it does not stimulate the development of production locally, it does not help to solve social problems, reduce economic security. The

Tab. 3. The share of the EU states in the foreign economic activity of Lviv oblast, 2005-2015

\begin{tabular}{|l|l|l|l|l|l|}
\hline \multicolumn{1}{|c|}{ Type of business activity } & 2005 & 2010 & 2013 & 2014 & 2015 \\
\hline Export of goods & 71.8 & 64.2 & 67.2 & 72.2 & 71.9 \\
\hline Import of goods & 41.3 & 31.6 & 63.9 & 79.2 & 81.5 \\
\hline Export of services & 75.8 & 71.0 & 71.3 & 65.7 & 68.5 \\
\hline Import of services & 84.8 & 88.1 & 81.4 & 76.9 & 66.6 \\
\hline
\end{tabular}

Source: Зовнішня торгівля ..., 2016. 
reforms in the state taxation legislation, especially in area of the production tax will help to changes this tendency, which will drive the creation of industrial enterprises in Lviv oblast and reduce the volume of imported goods (home appliances, products of the light industry, etc.). There are high hopes for the functioning of the industrial park and the industrial cluster.

\section{Conclusions}

The European integration for Ukraine overall and Lviv oblast in particular is a way to enter the global economic landscape and solve many urgent socioeconomic problems, the most important of which are the national security, technological obsolescence, unemployment, corruption etc.

Lviv oblast has a favorable economic and geographic location and borders with Poland - the EU state, it is also characterized by the medium indicators of demographic development and below average indicators of socio-economic development across Ukraine.

One of the oblast's common problems is the growing "shadow" economy, which is caused by the increased taxation pressure by the state, corruption, legal nihilism, the low culture of social responsibility of businesses.

The positive side of structural development of the economic sector of Lviv oblast is an increase in the size of small and medium businesses, the formation of the dynamic information and communication sector, the establishment of three clusters and one industrial park. The remaining problem is the large bankrupt, not competitive enterprises owned by the state and significant polarization in the economic development of the oblast.

The implementation of the reindustrialization policy will enable Lviv oblast to modernize active industrial enterprises; foster the development of alternative energy sector; create small businesses in the light, woodwork, and engineering sectors; create industrial clusters, the functioning of which will be based on the principles of sustainable development. This will significantly increase the investment attractiveness of the oblast, improve its investment and innovational climate, facilitate the development of foreign economic activity and strengthen regional and national security.

At the same time, "the shadow" economy, slow and ineffective implementation of economic reforms, their inconsistency and contradiction, negatively affect the modern economic development of Lviv oblast, preventing it from using the benefits of favorable location close to the border, the oblast's demographical and natural resources. In order to stop further stagnation in the oblast's economic development and implement the principles of the European integration, it is important to introduce effective and fast reforms of the political and economic system of the state, which will guarantee the country's choice of the European integration.

\section{References}

Bajda P., 2011, Stosunki UE-Ukraina - stan obecny i perspektywy na przyszłość, Ośrodek Myśli Politycznej, Kraków, http:// www.omp.org.pl/artykul.php?artykul=254 [29.12.2016].

Fiszer J., 2015, Kryzys integracji europejskiej czy kryzys Unii Europejskiej? Przesłanki i skutki, Przegląd Europejski, 3(37), 82-108.

http://della.com.ua/distance [11.01.2017].

http://www.d-maps.com [04.01.2017].

Kawałko B., 2011, Wybrane problemy polsko-ukraińskiej współpracy transgranicznej, Barometr Regionalny, 2(24), 35-60.

Świtała R., 2014, Integracja Ukrainy z UE. zagrożenia utrudniające poprawne ułożenie stosunków polskoukraińskich, [w:] Międzynarodowe stosunki gospodarcze: nowe wyzwania współczesnej gospodarki światowej, Studia Ekonomiczne Uniwersytetu Ekonomicznego w Katowicach, 184, 124-133.

Балабанов Г., Нагірна В., Нижник О. (eds.), 2003, Трансформаційна структура господарства України: регіональний аспект, Міленіум, Київ.

Головне управління статистики у Львівській області, http://www.lv.ukrstat.gov.ua [01.02.2017]

Гукалова І., 2009, Якість життя населення України: суспільно-географічна концептуалізачія. Монографія, Друкарня МВС України, Київ.

Державна служба статистики України, http://www. ukrstat.gov.ua [01.02.2017].

Діяльність суб'єктів господарювання Львівської області. Статистичний збірник, 2016, Головне управління статистики у Львівській області, Львів.

Зовнішня торгівля Львівської області. Статистичний збірник, 2016, Головне управління статистики у Львівській області, Львів.

Інвестиції у Львівській області. Статистичний збірник, 2016, Головне управління статистики у Львівській області, Львів.

Качаєв Ю., 2008, Принципи та напрями удосконалення територіальної організації інвестиційної діяльності в Україні, часопис сочіально-економічної географії, 5(2), 45-53.

Кравців В., Мельник М., Анонов В., 2011, Залучення прямих іноземних інвестицій в економіку України: проблеми та політика активізації. Монографія, Інститут регіональних досліджень НАН України, Львів. 
Львівська область у цифрах 2015. Статистичний збірник, 2016, Головне управління статистики у Львівській області, Львів.

Мезенцев К., Підгрушний Г., Мезенцева Н., 2014, Регіональний розвиток в Україні: суспільно-просторова нерівність і поляризація, Українське географічне товариство, Київ.

Мікула Н., 2004, Міжтериторіальне та транскордонне співробітництво, Інститут регіональних досліджень НАН України, Львів.

Назарук М., 2008, Львів у XX столітmі: сочіально-екологічний аналіз, Українська академія друкарства, Львів.

Нємець Л., Олійник Я., Нємець К., 2003, Просторова організачія сочіально-географічних прочесів в Україні, Харківський національний університет імені В. Н. Каразіна, Київ-Харків.

Пилипенко І., 2015, Суспільно-географічна периферія: концепиія, параметризація і делімітація, Видавець Грінь Д.С., Херсон.

Підгрушний Г., 2009, Промисловість і регіональний розвиток України, Інститут географії НАН України, Київ.

Смаль В., 2011, Трансформація господарства постіндустріальних країн: наукові засади суспільно-географічного дослідження, Видавець Лисенко М.М., Ніжин.

Статистичний щорічник Львівської областіза 2015 рік, 2016, Головне управління статистики у Львівській області, Львів.

Стеченко Д., 2002, Інновачійні форми регіонального розвитку, Вища школа, Київ.

Україна у цифрах 2015. Статистичний збірник, 2016, Державна служба статистики України, Київ.

Шаблій О., 2001, Суспільна географія: теорія, історія, українознавчі студії, Видавничий центр Львівського національного університету імені Івана Франка, Львів.

Шимонович Й., 2001, Економіка України. Наукові праці, Видавничий центр Львівського національного університету імені Івана Франка, Львів. 